\title{
Rethinking Non-Racialism: Reflections of a Selection of South African Leaders
}

\author{
FIONA ANCIANO-WHITE* AND JOHNNY ALUBU SELEMANI**
}

\begin{abstract}
Drawing from in-depth interviews with 26 prominent South Africans, this article looks at how leaders in government, political parties, business and civil society understand and interpret non-racialism today. It interrogates whether non-racialism is an active political and social project among leaders in South Africa and whether, and how, they are attempting to redefine nonracialism. The article demonstrates that non-racialism is a term still ambiguously understood and defined by South African leaders. Some respondents consider races to be products of social construction and, as such, believe these constructions can be transcended. For many, however, the idea of multiracialism prevails over that of non-racialism. Although non-racialism remains largely a rhetorical ideal among many leaders, respondents did have well-defined views of the challenges facing non-racialism, particularly those of socio-economic inequality and poor leadership from the African National Congress (ANC). Overall, there is a strong sense from many respondents that the values of nonracialism are currently under threat. However, through using social sectors such as education and the media, as well as fostering open debate on non-racialism and facilitating stronger leadership from all areas of society, interviewees did see potential for building a path toward a non-racial South Africa.
\end{abstract}

I really think that the whole non-racialism question, in a strange way, haunts all of us in this country... We have made major advances as a society; breaking with the institutionalised and ideologised racism of the apartheid era. The question is what do we do with our freedom? Can we really break new ground, not just for ourselves, for the world in many ways? There is an exciting challenge in our midst, and we shouldn't lose sight of that. (Satgar, interview, 31 August 2011) ${ }^{1}$

\section{Introduction}

The concept of non-racialism, according to the anti-apartheid activist Ahmed Kathrada, sat at the heart of the anti-apartheid struggle. Certainly, Everatt 
(2009, p. 1) agrees that '[a]mong the most consistent threads in the discourse of liberation in South Africa was a commitment to non-racialism'. Where do we find the non-racialism project in 2011, 17 years after the transition to democracy? Is the institutionalised and ideologised racism of the apartheid era a concern of the past? Have we broken new ground in race relations? This article draws on interviews with 26 prominent South Africans in an attempt to answer these questions. Specifically, it looks at how South African leaders understand and interpret nonracialism today. It interrogates whether non-racialism is still an active political and social project among leaders in South Africa and whether, and how, they are attempting to redefine non-racialism.

These are critical questions to unpack in the context of recent research (Ahmed Kathrada Foundation (AKF)/Gauteng City Region Observatory (GCRO), 2011) demonstrating that South African society as a whole is still racially structured, and that South Africans are struggling to define the concept in their individual environments. The role leaders play in creating meaning from the nebulous concept of non-racialism (see Everatt, 2011; Maré, 2003; Maré and Kinners, 2011) is crucial to any political or social project that hopes to move South Africa's history on from one of deeply racialised apartheid.

\section{Methodology}

This article is the product of a research project initiated, structured and funded by the Ahmed Kathrada Foundation. The project aim was to enable the Foundation, through interviews with key public and private sector and civil society leaders in South Africa, to gain a comprehensive understanding of the definitions and meanings of non-racialism. It intended to strengthen and supplement a growing body of research across a broad spectrum of South Africans, to (a) elicit meanings of nonracialism as described by leaders in contemporary South Africa; (b) arrive at a collective definition(s) of non-racialism offered by leaders; and (c) tease out what a non-racial South African society might look like (AKF, 2011). The project focused exclusively on leadership views, as this is an under-researched area and complemented the focus group work carried out by AKF/ GCRO (2011) looking at non-racialism in society.

In order to achieve the project goals the Foundation targeted approximately 35 respondents for interviews but, after non-responses, 26 interviews were conducted. Research subjects were chosen based on their representation of a broad range of sectors and political views. Subjects were chosen from Ahmed Kathrada Foundation board members; the African National Congress (ANC); the South African Communist Party (SACP); Congress of South African Trade Unions (COSATU); the ANC Youth and Women's Leagues; the Democratic Alliance (DA); faith-based leaders; private sector leaders; civil society leaders; leaders in the media and, finally, non-aligned prominent individuals. The choice of subjects was discussed in detail by the Foundation's director, its research project manager and researchers involved in the project. The final list of interviewees was further presented to, and discussed at, a Foundation board meeting in August 2011. Based 
on experience, organisational position and public exposure, respondents were viewed by the Foundation and research team as leaders in their field. Those interviewees who are not currently actively working in organisations or political structures have previously held leadership positions.

The views expounded by these leaders shed light on how senior decision makers and thinkers in different sectors of South African society understand the opportunities and challenges of non-racialism. However, the sample of 26 is only indicative of thinking at leadership levels and cannot be generalised to offer a comprehensive view of the non-racial project in South Africa. Although they highlight important themes in the creation (or not) of a non-racial society, the interviews are best understood as indicators of thinking by individual prominent South Africans at a particular point in time.

The research design for the project focussed on a qualitative set of in-depth, semi-structured interviews. This method was chosen to 'allow people to answer more on their own terms. . . but still provide a greater structure for comparability' (May, 2001, p. 123). Semi-structured interviews offer a degree of latitude to the researcher and sensitivity to context and content of the interview. They also allow for questions to be re-ordered during the interview, and for unscheduled probes (Berg, 2004, p. 81). This latitude was important in gathering honest and relevant feedback for the questions. Some questions could be seen as sensitive issues for certain respondents, and so flexibility was needed in the phrasing and delivery of questions. The researchers, in conjunction with the Foundation, designed a set of open-ended questions which were piloted in interviews with several of the Foundation's board members. Once the questionnaire had been refined, the remaining interviews were conducted between July and September 2011. The interviews, which were around an hour long, were taped and transcribed. Interviewees gave permission for their interviews to be cited.

\section{The meanings of non-racialism}

Unpacking the meanings of non-racialism is a challenging task. Attempts have been made to explain how the concept is applied in South Africa (Everatt, 2009; Maré, 2003; Taylor, 1994); however, as Everatt (2009, p. 1) explains, since 1994 there has been a critical failure to define non-racialism, 'to give it content beyond that of a slogan of a self-evident "good thing". Indeed, this research demonstrates that the meaning has changed as the political context has changed.

In this research we found that relatively few respondents had clear definitions of the idea of non-racialism; they frequently talked around the concept rather than defining it. However, drawing from respondents' comments we were able to extrapolate two main ways in which non-racialism is understood by the leaders interviewed: 'ascending race' and multiracialism. The idea of 'transcending race' closely follows Maré's (2003) argument that within the strict meaning of non-racialism, there are no such things as biologically or genetically determined, 
objectively verifiable, socially meaningful categories called races. In other words, race is a social construction and as such we can 'ascend' this social construction.

In this view, non-racialism is fundamentally about not judging people by their colour; rather, it is 'understanding people as people and not as a particular group' (Gandhi, interview). Non-racialism as 'transcending race' essentially looks beyond race, and as such is 'almost a vision of the future, a utopia' (Ngwane, interview). For Deputy Minister of Science and Technology Derek Hanekom, race is a social construct: '[B]iologically it is absolute nonsense, but you have to get to the point where it is socially nonsense as well'. Faith-based leader Frank Chikane agrees that race is created and socially constructed and that to 'undo it you have to change the structures that created it'.

ANC chairperson Baleka Mbete elaborates on this view, seeing non-racialism as a 'society where the question of racial considerations plays no role in determining what happens to people, what they are entitled to, what their role and place should be in life'. In a similar vein, for DA leader Helen Zille 'non-racialism is approaching each person as a unique individual and not merely as some kind of representative of a category'. For ex-ANC Minister Barbara Hogan, non-racialism 'wasn't just a struggle concept that was used to fight against apartheid... it was something more fundamental... It's the universality of our humanity... it's a statement of human rights, of equality, of how we all belong in one earth'.

Within the idea of transcending racial categories, however, many respondents held onto the importance of accepting and embracing multiple identities. This was not seen as counter to the idea of moving beyond racial categorisation. Via the induction and practice of a set of values and principles, City Press editor Ferial Haffajee argues, for example, that you could 'transcend the racial wounds of the past... get past racial divisions, without giving up your core identity'. For many who embrace this idea, the achievement of a common South African identity is paramount, but within the context of respecting individual identities and cultures.

As newspaper editor Mondli Makhanya explained:

[Non-racialism] is about constructing a society that appreciates the fact that we are diverse, that we come from different places, spaces, cultures and religions, but that there is a concept of South Africanism. That, at the end of the day, we are in a pot, and we are cooking in one pot, and that, in accepting the fact that we are different, there is a lot more that is common about us than is different, and that our differences are in fact our strengths.

Hanekom agrees, noting that non-racialism has to encompass a society where there is a common identity as 'South Africans', but with the recognition of 'what is important to people', including cultural and linguistic diversity. The challenge is to nurture and respect multiple forms of identity within the context of a common identity as South Africans. For Deputy Minister of Transport Jeremy Cronin, the 'tradition of non-racialism in the ANC has never been about denial of diversity in South Africa'. Similarly, for Prema Naidoo non-racialism must respect and appreciate people's religious, cultural and linguistic backgrounds. Consolidating this view, Member of the Executive Council (MEC) for Transport in Gauteng Ismail Vadi argues that non-racialism is about 'asserting the positive 
identities of people'. It is important to have a shared loyalty to a South African identity, to a single nationhood, and to a single political system, based on constitutional principles. However, Vadi also subscribes strongly to the idea of multiple identities:

I am a South African but I am also an Indian, I cannot discard my heritage. I love my Indian food... and Indian music, Indian languages, but I'm also a Muslim. So I have a religious identity... So you may be a male, an Indian, a Muslim, a South African... All those things contribute to the construction of identity.

Although many respondents embraced the idea of non-racialism as a long-term value to strive towards, others recognised that, in practice, the idea of multiracialism prevails. Multiracialism is defined as the "equality of political representation and social acceptance in a society made up of various races' (American Heritage Dictionary, 2009). In the South African context, Maré (2009) explains that multiracialism refers to a society of more than one race where it is accepted that there are essential biological differences between these race groups. Although differences are recognisable through racial appearance, multiracialism does not embrace the idea that one race is superior to another. Those respondents who support the idea of multiracialism implicitly embrace the idea of socially constructed racial categories, but in some cases see this as a step toward achieving a society that looks beyond race. ANC Secretary General Gwede Mantashe explains: '[E]ven today when we talk of non-racialism, the elements of multiracialism come to the fore. . keeping identities of people in different races', but notes that the ideal of non-racialism is a situation in which race and colour will not be an issue, and believes that this is the ideal to strive for.

Indeed, historically_although the 1955 Freedom Charter articulates the goal of a non-racial society (Motlanthe, 2010) — there has been, according to Managing Director of the Banking Association of South Africa, Cassim Coovadia, 'a need to categorise people into race, tactically, because the reality of the situation was that Black African people... were the most oppressed; while Indian and Coloured people were oppressed as well, the degree of oppression was not as severe... So the different races at that time found themselves under different conditions and different contexts'. Cachalia takes the argument further, explaining that although idealistically non-racialism could be about overcoming racial identity, for him it is about overcoming inequalities based on race. Youth League spokeswoman Magdalene Moosamy agrees: for her, non-racialism means that 'we need to address issues of the past' based on assumptions of power and class, and that 'we need to reaffirm the inequalities of [Black] Africans in particular'. As activist Vishwas Satgar notes, the perception of multiple races was inherent in the idea of the 'rainbow nation', which had an effect on nation building.

Almost all respondents took the view that South Africa currently needs to recognise and acknowledge colour difference because of the distorted legacy of apartheid. Historically entrenched social, economic and class differences mean that, in practice, some races are more disadvantaged than others, and this needs to be addressed. As Hogan notes, historically, "non-racialism emerged as a fight 
against racism'. Former ANC Member of Parliament (MP) Laloo Chiba also explained that non-racialism resulted from a need to have 'unity in diversity', while former Justice of the Constitutional Court Arthur Chaskalson agrees that you cannot talk about a non-racial society without acknowledging differences that come from the past. As appropriate as this view is, its consequence is that South African leaders are not currently focused on moving beyond racial difference but practice a combination of multiracialism and multiculturalism, ${ }^{2}$ with the end goal of non-racialism. Insights from this project's interviews underpin that Maré's (2003) views remain accurate: South Africans' commitment to nonracialism in effect reflects common-sense thinking based on the existence of races, and is in reality actually multiracialism rather than non-racialism. The implicit (or explicit) embracing of a multiracial view by many leaders in society and government has consequences for economic and social policy in South Africa. As the following section in this article will demonstrate, policies such as affirmative action (AA) and black economic empowerment (BEE) ironically embrace and uphold apartheid racial categorisations that many anti-apartheid activists fought to undermine. This raises the question of whether supporting multiracialism in the short to medium term poses a significant challenge to building non-racialism in the long-term.

Indeed, many respondents see building a non-racial state as a long-term process, not an event. For Vadi, even in societies where there is no racism, racial identities still exist; what apartheid did was give institutional form and character to racial identity. Eroding this form of socialisation in South African minds will require a process, not a 'moment'. Building a non-racialist society is a moving targeta process of constant engagement in order to change apartheid-constructed consciousness. However, despite the validity that transforming society is an ongoing process, this research indicates that many South African leaders have not clearly articulated what success in building non-racialism would look like. The lack of clarity in many interviewees' definitions of non-racialism was apparent when questioning them about what they believe the key features of a non-racial society to be; most either did not answer the question or turned first to dealing with challenges to non-racialism, and how to overcome these.

Significantly, in terms of policy formulation, leaders involved in the act of governing - specifically, those representing the ANC — do not have a shared understanding of the meaning of non-racialism. This is most aptly demonstrated by the different views espoused by the ANC chairperson (Mbete, interview) and secretary general (Mantashe, interview). In the former's interview there was a sense of resigned acceptance that racial difference was important to embrace in the short term as a means to achieving greater economic equality, but that the ideal to strive for was a policy that is not constructed based on racial lines. The latter, however, indicated that racially based policies would be in place for a very long time and that this was not problematic in building a united South African society. Thus, as Maré argued (2003, p. 15), non-racialism appears to remain 'a largely unexamined rhetorical commitment to an ideal'. The lack of clarity around defining non-racialism indicates that, even with the best of intentions, the majority of 
leaders interviewed have not actively attempted to redefine non-racialism in postapartheid South Africa. Without a clearly defined set of goals and practices to strive for, the journey to non-racialism is more complex and potentially longer. This raises the worrying possibility that building a non-racial society may not be a significant social and political project for South African leaders today.

\section{Challenges to building a non-racial society}

Although for many leaders interviewed, non-racialism largely remains a nebulous ideal, clearer thinking on the concept emerged when respondents were questioned about the challenges to building a non-racial society. For many respondents, the legacies of apartheid present the most significant challenge to achieving a nonracial society. This is consistent with the notion that non-racialism, as a concept, emerged out of the struggle against apartheid (Everatt, 2009; Frederikse, 1990). For respondents, building a non-racial society is hampered by the entrenched notions of race that have been socialised into South Africans. Even with the most noble of ideas, it is hard for most people to see beyond colour as an initial marker of identity. However, for many interviewees, the most damaging legacy of apartheid is the enduring socio-economic inequality between races and classes. The following section will discuss spatial challenges to non-racialism and the impact of current political realities, including the role of the ANC and relationships between different race groups on building non-racialism.

\section{Socio-economic inequality}

Almost all respondents focused strongly on the idea that historical social and economic inequalities must be addressed before there can be a meaningful transformation that will result in a non-racial society. For Vadi:

In a situation where there is significant inequality in society, in a situation in which socioeconomic relations have not equalised, race will still remain a critical factor... With the best will in the world, a desperately poor [Black] African person will look at a rich Indian person, a rich White person, in a different way. And, in his or her mind, the thought might come, how come Whites and Indians have so much that I don't have? He is asking a legitimate question on the basis of his economic deprivation. So, in a society of inequality... race will remain a factor.

Certainly Moosamy and Cachalia agree that if you want to change racial attitudes and perceptions, you have to change the economy of the country. Moosamy, however, takes the argument beyond equalising socio-economic relations, maintaining that 'economic power must shift from the [White] minority to the [Black African] majority'.

Allied to historical social and economic inequalities is that of class and nonracialism. South Africa's past, like the pasts of other parts of the colonised continent, is made up of a working class that consisted primarily of Black Africans, Indians and Coloureds, with White elites controlling economic power. This 
established a top-down system of racial categorization which manifested itself in the form of class relations between Whites, Coloureds, Indians and Black Africans. The key feature of this class distinction was economic control. For Satgar, ' $[\mathrm{t}]$ he relationship between race and class and how these intersected served to reproduce the pattern of racial oppression.'

Most respondents feel the best way to address the historical legacy of inequality is through programmes such as AA and BEE. To a much lesser extent, some mentioned land reform. Many respondents agreed that the rationale behind AA and BEE is good, necessary and appropriate to deal with historical legacies. Kathrada commented: "We came into government on the understanding that a priority is... the most oppressed, and the most oppressed were the [Black] African people, the majority'.

Notwithstanding the necessity of AA and BEE, the majority of interviewees spoke about tensions emerging from these policies. Broadly speaking, they discussed problems with poor implementation of the policies, the concern that they inadequately addressed redistribution, and the concern that they may create a sense of marginalisation in sections of society. Questions arose about whether these programmes go far enough in changing the conditions of previously disadvantaged races. For Muslim scholar, writer and anti-apartheid activist Farid Esack, BEE had the theoretical basis of affirming all of the historically disadvantaged communities, yet in practice it is not connected sufficiently "with the very genuine grievances and poverty that exists in black townships and the need to address that'. COSATU's president, Sidumo Dlamini, agrees that BEE policy 'continues to serve a few blacks only'. As Vadi notes, after 17 years of democracy, we have higher levels of inequality in society, despite the government's official programme and project being the reduction of inequality.

A further concern with regard to these policies is the question, framed by Hogan, of how to address historical inequality without creating a sense of marginalisation. How do you use programmes such as BEE and AA to 'set the balance right' while supporting non-racialism? These programmes can lead to a sense that minority groups are becoming marginalised second-class citizens. For Kathrada, the concern about BEE is that it marginalises non-black (African) races that were disadvantaged by apartheid: 'it has become basically a Black African thing. It was meant to be for all formerly oppressed people'. De Klerk argues that although necessary, programmes such as AA and BEE must not be implemented in way which constitutes institutionalised discrimination: 'I think the how of affirmative action, the unbridled and unchecked racist rhetoric within the governing party, but also in other places, is militating against taking the whole nation along on the road of non-racialism. It is creating more divisiveness'.

Cachalia provides an insightful view of how policies such as AA and land reform can have negative unintended consequences for non-racialism:

There is a dilemma here, you can't target disadvantage without identifying the target group, and if you are targeting racial inequalities then you need public policies that take race into account. But. . you reinforce racial identities; you create incentives for people to identify on 
the basis of race. You imprison others in a narrow racial category which they do not accept, quite rightly. And I think you create incentives for people to trade on colour, ethnicity, race, because it is a source of privilege, access, opportunity. So any public policy has costs here, we should be aware of that.

For many respondents, breaking down socio-economic inequality is a long-term project. As Mbete noted, programmes that address inequalities are working towards an end goal where a balance begins to materialise. However, 'how long that will take, I don't think any of us will be able to say'. The challenge to building non-racialism in the short term, however, must not be underestimated. Equalising socio-economic relations between races is a crucial step in building an economically stable and more cohesive society; however this research demonstrates that many leaders in society and government could dedicate more focus to how (or whether) non-racialism can be fostered while economic policies based on racial difference are in place.

\section{Spatial challenges and socialised racism}

A further challenge to non-racialism deriving from the history of apartheid, and in particular the Group Areas Act, is spatial or geographic division. As Hogan and others explain, apartheid divided races in fundamental ways, particularly with the location of Black Africans outside of cities. Cronin and Makhanya believe this spatial crisis is ongoing, particularly with the continuation of building apartheid spaces through Reconstruction and Development Programme housing. For Cronin, people are 'crammed into horrible dormitory townships... and still treated as if they are migrants, they are here in the city to sleep and work'. He asks, 'why aren't we de-racialising towns and cities?', and concludes that there is a need to think profoundly about thorough spatial transformation. One solution he offers is the possibility of public transport playing an effective role in 'transforming and de-racialising geography'.

A second concern arising from spatial challenges is that separate living between races promotes 'ignorance and fear': where there is no fusion of culture, no conversation across colour lines, and where people live in racially separate areas, disputes become racially biased: 'you end up with racism, xenophobia, tribalism, racial wars; because people don't know each other' (Esack, interview). Vadi agrees that having separate spaces for different races results in particular racial or ethnic consciousnesses developing. This correlates with several respondents' (Mbeki, interview; Gandhi, interview; Ngwane, interview; Chaskalson, interview) expressed views that racism, as a consequence of apartheid, is a phenomenon that has been socialised into South Africans: due to years of indoctrination, people have been taught to believe they are different, and that there is a superior and an inferior race (Gandhi, interview). Ngwane tells a personal story regarding the effect of socialisation:

I grew up in a kind of cocoon in a missionary hospital, where there was an attempt by those in charge to be very non-racial. So when... I went to Wits University and I saw all those 
Whites; to me they were just human beings. But I soon realized that other students didn't think that way, they had grown up in isolation from White people, and the White people they knew were the police, were the bad guys... They had an almost inherent, socialized suspicion, even fear, hostility to White people, which I didn't have.

Other concerns linked to spatial challenges include racial separation taking place, indirectly, in the workplace. There is a need to transform the workplace at a much more rapid rate, implementing meaningful policies rather than 'just ticking boxes' (Makhanya, interview). Finally, the lack of a single, nation-wide language, and the existence of a number of separate languages, are seen as a challenge to building non-racialism (Hanekom, interview; Mbete, interview). As Makhanya notes, it is 'intrinsically divisive' when people cannot understand and respond to what other people in a room may be saying.

Many respondents (William-De Bruyn, interview; Mantashe, interview; Mbete, interview) hold the belief that racism will be undermined where different races live in the same communities and neighbourhoods, start to practice their different cultures within the same society, or indeed intermarry. Former President Mbeki agrees that "you will be able to tell if there is progress in terms of non-racialism just by watching the way the population is moving'. Although evidence suggests that the greater the amount of interracial contact, the lower the amount of racial prejudice (Gibson, 2004; Finchilescu et al., 2006), it is also apparent that there is continuing racial isolation in the country. According to research by Finchilescu and Tredoux (2008), in post-apartheid South Africa there is little intimate contact between races, and few cross-race friendships or marriages are formed. Furthermore, this is not explicable as a function of differences in spatial demography, as South Africans tend not to make cross-race friends even in shared environments such as universities. Finchilescu and Tredoux's research highlights the need for South African leaders to think more profoundly about how to foster non-racialism in a society that has seen relatively little racial integration over the past 17 years.

\section{The ANC}

After addressing the impact of legacies of apartheid on building non-racialism, respondents turned to challenges posed by contemporary political realities. Firstly, concerns over the role of the ANC in fostering non-racialism were raised by many respondents. This is somewhat disconcerting given the party's promotion of the Freedom Charter and, after 1969, its acceptance of multi-racial membership. ${ }^{3}$ However, before turning to ANC-related concerns, it is important to acknowledge that support for the ANC's actions was also expressed. Naidoo, for example, notes that the deployment policy in the national cabinet ensures a non-racial mix of ministers, even in the context of a support base that is almost entirely Black African, while Hanekom feels there has been an increase recently in the ANC leadership's focus on non-racialism, stating that it 'has found its way more back into the ANC discourse', with various key people delivering addresses that focus on non-racialism. 
While bearing in mind the ANC's positive actions, the majority of respondents nevertheless raised some concerns over the ANC's current role in promoting nonracialism. Interviewees including Coovadia, Williams-De Bruyn, Naidoo and Hafajee all feel the ANC is 'slipping' in its approach to non-racialism: respectively, 'we've just lost the values we grew up with'; 'our people have lost sight, they have forgotten'; 'the organisation hasn't become different, but it's slipping'; and 'I think the ANC, in its hundred years, it's been through epochs of greatness, and times of poverty of thought and mediocrity, and I think it's in one of those dips at the moment'.

Several reasons were put forward for the ANC's inadequate promotion of nonracialism. Firstly, respondents feel that ANC leadership around non-racialism is weak. For example, according to Esack, they are silent in the face of more populist, sometimes blatantly racist views from elements of the Youth League. ${ }^{4}$ Coovadia agreed that the ANC 'has not taken the Youth League to task' for racial statements they have made. There is a need for the leadership to continuously promote non-racism. Indeed, Mantashe did concede that 'the ANC must be bolder in its pronouncements on non-racialism'.

Secondly, respondents feel that the ANC does not adequately promote non-racialism because it is concerned with holding onto political power, to the detriment of other issues. Haffajee feels there is little space for 'thinking' and that the ANC is curerntly going through a stage in which all it does is roll from one election conference to the next, which causes tension and 'fighting'. For Ngwane, the real challenge is the difference between the ANC as a national liberation movement and a government in power: 'If you are in power, the first priority... is to keep in power... they will use non-racialism, not so much to get rid of racism, but to ensure their rule over society'.

A final criticism of the ANC with regard to non-racialism is that it has insufficiently focused on building non-racialism at the grassroots level. For Naidoo, the ANC leadership could do much more to encourage racially diverse membership at lower levels of the organisation. Vadi agrees that fewer and fewer White, Indian and Coloured leaders are beginning to emerge in the ANC. Mantashe maintains that the ANC is very conscious about its structures being representative, and even goes 'the extra mile to correct imbalances'; however, he is also concerned that the movement is not seeing new activists coming through its ranks. Ensuring diversity is a challenge due to being 'stuck' with the groups 'we know in those communities'. Many respondents feel the time has come for the ANC to reflect on its approach to non-racialism. For Cachalia, now that the ANC operates under conditions of mass democracy, it needs to rethink some of the ideas on non-racialism that were formulated in the 1950s. Formulations to some extent have been static; they need to be more nuanced, more complex, and more adequate to meet the current challenges.

Drawing from respondents' views, and recognising the ANC's significant historical contribution to building a non-racial state, there is a strong sense that the ANC has lost its way regarding non-racialism and is not providing effective and cohesive leadership and vision. Certainly, when discussing the meanings of non-racialism, 
different views emerge from different leaders and sectors of the party about the fundamental meaning and practice of non-racialism. Many respondents, often members and/or leaders of the ANC themselves, feel the movement is struggling to formulate a cohesive approach to the idea and implementation of non-racialism.

\section{The ANC Youth League}

Given the timing of this research (mid-2011), it is understandable that the role and leadership of the ANC Youth League featured prominently in the interviews. A key concern of several respondents was that the Youth League is promoting a racial agenda and that, given the socio-economic status of many young Black Africans, this view is finding resonance among the youth. The views put forward by the league are, according to Haffajee, 'very, very influential'. She explains that studies from media research in South Africa show that (former) leader of the Youth League Julius Malema is now the. . second most commonly-cited political individual in South African media. ${ }^{5}$

A number of interviewees expressed concern that Malema is encouraging racial views. Haffajee commented 'I don't know what he is, but he certainly isn't a nonracialist', while Makhanya feels 'the Youth League spews out comments that are racial, racial, racial'. To counter this view, however, the League's spokesperson Madeleine Moosamy argues that 'The ANC Youth League has at no point raised the issue of race with the intention of advocating racism' ${ }^{6}$ While at face value this may be true, in practice it could be argued that racism is implicitly endorsed in examples of racial statements from the League such as 'all Whites are criminals and thieves' which were raised by respondents. For Hanekom, the League's 'racial' statements do not 'help to infuse and encourage a change of attitude'. Makhanya felt the statements are 'dangerous, and alienating, and will serve to make a section of the population feel they do not belong here and they are not as South African as everybody else'. Mantashe too expressed concern that some of the views expressed by the League could alienate sections of society.

In light of the reality of continuing socio-economic inequality, commentators, including Vadi, maintain there is "nothing wrong with the Youth League raising issues of economic empowerment... strongly', but that 'the roundedness is what I don't see, the sophistication and strategies are not coming out, and perhaps its leadership, in the way in which it is raising things, is adversarial rather than constructive'. Mantashe agrees that 'sometimes they raise relevant issues', such as the nationalisation debate. However, he follows by noting that the style and manner in which issues are raised by the League can be damaging:

We say, listen, society works differently. If you go out and say 'Whites stole land and they are criminals' it is not helpful. It may be the same message as saying it is not sustainable to have the current distribution of land. But the reaction and the impact is not the same. The language used alienates society.

A further indicator of the League's non-racial (or otherwise) stance arose with regard to its membership. Several respondents noted that the leadership is 
'almost exclusively [Black] African': 'When I sat in their conference I didn't see again any other race group, except one Indian woman... it was wrong... they should have had foresight to say we know the ANC stands for non-racialism... let us start recruiting people from other race groups' (Williams-De Bruyn, interview).

While the Youth League attracted the strongest criticism for its lack of focus on building non-racialism, the ANC Women's League and the South African Communist Party did not escape attention. Vadi remarked that there is no focus on non-racialism coming out of the Women's League, while Esack commented that the SACP, 'who has a far more principled position on questions of non-racialism is mostly silent'. However, it is important to conclude this section by noting that building non-racialism cannot be a task left solely to the ANC and its affiliates. Certainly in the early 1990s, the ANC was 'imbued with the nation building responsibility', and this was expressed in the Mandela era. Yet, for Vadi, 'no political force is "infallible" or has the capacity to do everything'. South Africa must keep alive a people-centred notion of non-racialism.

\section{Relations between race groups}

A further challenge to non-racialism that was raised by several respondents is the view that there is ongoing racism between all race groups in South Africa. The poor relations between Black Africans and Indians and Black Africans and Coloured people are of particular concern. In relation to Black African-Indian relations, Ngwane and Gandhi point to KwaZulu-Natal particularly and note that racism is reciprocal, with antagonisms coming from both the Indian and the Black African side. For Ngwane, although there is antagonism from Indians towards Black Africans, Black Africans have 'their own reverse racism... there is a strong anti-Indian ideology, and it is spoken about'. Racism between Coloureds and Black Africans is also seen as troubling, in this case particularly in the Western Cape. Respondents gave several reasons for these problems. First is some Black Africans' perception that Indians and Coloureds have taken advantage of economic opportunities, such as AA and BEE, to their detriment. For Esack, it became clear that Black Africans felt there was a disproportionate number of Indians and Coloureds in the civil service, 'and people then started talking about "real" Blacks... so now there is a much more unashamed articulation of privileging "real" Blacks'. In response to this, according to Hanekom, many in the Coloured community in particular feel that 'before I wasn't White enough and now I'm not Black enough'. This has caused resentment and frustration toward Black African leadership.

A further anxiety is the sense of alienation that Coloured and Indian communities may now feel from the ANC. For Williams-De Bruyn, certain ANC leaders 'made utterances' that 'drove other race groups away from local elections'. Coovadia agrees that by and large, the Indian and Coloured community do not consider the ANC to be acting on their behalf; consequently, they have switched party allegiance. Coovadia argues that this reaction is primarily a result of the 
ANC placing greater emphasis on racial issues than core problems such as education. Much of this sense of separation has arisen due to remarks made by Head of Government Communications Jimmy Manyi to the effect that there was an over-concentration of Coloured people in the Western Cape. For Chiba, influential people such as Manyi 'make the wrong derogatory statements' which are not 'in the spirit of non-racialism'. Similarly, for Cronin, Malema's 'strident anti-whitism' has opened a space for the DA to win support from minority communities. The DA framed their discourse as a non-racial one, but for Cronin, it was really about mobilizing minorities against the threat of majoritarianism, and Malema played into this.

The role of White South Africans in building non-racialism was also seen as an important challenge to the fostering of non-racialism. Several, in some cases very different, perspectives were offered regarding the responsibility of Whites in building non-racialism. ${ }^{7}$ Some respondents implicitly and explicitly noted that Whites should have shown more remorse for the repression that occurred under the apartheid system. The 'rainbow nation' celebration after 1994 was an important attempt to create a sense of being a South African. For Makhanya, however, there was insufficient confrontation of what had occurred under apartheid, 'that as a society we were scarred with racial scars, that we were damaged'. The notion of a rainbow nation was taken on and celebrated too prematurely, and thus the project was essentially artificial. Moosamy takes this perspective further, espousing a clear view that Whites hold responsibility for the challenges facing South Africa. She argues that 'the reality is that racism is entrenched in this society by the White minority' and that minority groups, and in particular Whites, have not committed themselves in general to the democracy. Cronin raises the point that White South Africans, including those born after 1994, need to recognise that they are the beneficiaries of apartheid. Access to privilege and advantage is still profoundly marked by race. White South Africans need to be "much more sensitive, and much more committed to changing the things that are perpetuating that reality'.

A second concern raised by respondents is that Whites who own and control wealth have not committed to non-racialism. Makhanya comments that 'White business had to be dragged kicking and screaming into implementing policies of redress; they didn't take to employment equity, it had to be legislated, there was no voluntary transformation'. Moosamy again takes this perspective further, arguing that the issue of race is at the heart of the majority's lack of prosperity, as the White minority still controls the economy, and that 'the only people who are not committed to non-racialism is White minority capital'. She argues that when White capital gives 'back to the state, then we would have resolved our problems'. In a similar, albeit more moderate, vein, Archbishop Desmond Tutu (2011) recently proposed that Whites should pay a small 'wealth tax' ${ }^{8}$ Several respondents, however, feel this would not alleviate racism in South Africa. Mbeki argues that the reduction of racially aligned poverty and inequality will not be achieved by redistribution; rather, the 'challenge is doing something about growing the economy'. For Cronin, non-racialism cannot be seen as a 'deal' in which Whites can buy moral absolution. 
Finally, when discussing the role of Whites and non-racialism, de Klerk and Hogan did raise some positive points. De Klerk noted that in the 1990 referendum, the overwhelming majority - 69\% — voted for change and wanted non-racialism to succeed. For de Klerk, it is clear that the vast majority of Whites are committed to the values, principles and goals of the constitution and want to build a truly nonracial state. Further, he argues that the internal debate in Afrikaner circles is becoming dynamic and the voices of moderation are intensifying their efforts to be heard, not wishing to be characterised by the 'utterances and philosophies espoused by what essentially is a clear minority within Afrikaner circles'. Hogan too says that she is "still astonished at how much goodwill there is from White South Africans' in the pursuit of non-racialism.

\section{Fostering non-racialism}

Although there is evidence that non-racialism is not currently a significant political project, the leaders interviewed nonetheless had numerous ideas about how it could be promoted. Logically, addressing the challenges raised in the previous section would be a first step toward building non-racialism; thus respondents talked broadly about reducing poverty and inequality, improving service delivery, addressing spatial divisions, and improving social integration. Two areas of intervention, however, were raised by almost all respondents: education and media. Alongside these, interviewees further stressed the importance of open and widespread debate. $^{9}$

The potential that education holds to promote non-racialism was framed in two ways: first, as a means to reduce poverty and so foster meaningful and long-lasting racial equality; second, as an avenue to teach and instil non-racial values in children. For Zille, 'the very basis of opportunity is decent education'. It is the role of the state to offer high standards of education so that citizens can use their political freedom to grasp opportunities to work hard to develop themselves. This will foster long-lasting economic change, where the previously disadvantaged will be able to equalise economic opportunities and so reduce poverty (Zille, interview). Naidoo agrees that if we 'get education right... we will go a long way to achieving transformation of society'. Other respondents (Mbeki, interview; de Klerk, interview; Naidoo, interview; Coovadia, interview) stressed the skills shortage in the country and the importance of building skills in order to improve the economy and so reduce poverty and inequality.

The second indication of the importance of education-instilling non-racial values in students - was widely articulated by a number of respondents. Kathrada, Ngwane and Gandhi all felt that children should be educated about non-racialism from a young age both in the home and at school. Kathrada 'wish[es] that whoever is responsible for the syllabus, would start right from the beginning with a policy of teaching kids non-racialism... it's easiest early on because kids don't know colour'. Gandhi clarifies that in the first seven years 'a child gets grounded', and so this is a vital time to support the child's conscious learning. Good education can reduce prejudice, because 'with prejudice, with discrimination, you close in 
and you don't want to allow any other views to come in. . you're never going to broaden your perspectives'. For Cachalia, public education can encourage people to 'reach beyond the racial stereotypes' and help them build social networks outside of their comfort zones. Hanekom takes the argument further, calling for a 'little bit of positive social engineering'; for example, the creation of school residences that are, by policy, racially mixed: 'you've got to almost enforce a situation where friendships can develop. By the time it happens at university, it is just too late'.

Although the importance of education in tackling racism was noted by most respondents, many also raised the challenges facing South Africa's education system and the ways that these challenges could undermine the efforts toward non-racialism. Cronin, for example, argues that education can be a reproducer of racialised inequality, particularly where it intersects with class realities: Some Black people are able to escape the reality of the township, but the majority aren't, and their education 'is just dreadful'. For Mbeki, language policy in schools can be problematic: 'I think part of the weakness of the education system... has been the failure to use people's native language as a medium of instruction'. Mbeki believes that schools need teachers who can instruct children in their home language. This is crucial to 'eradicate the legacy of the past'. While recognising the challenges facing the education sector, several respondents (Mbeki, interview; Makhanya, interview; Zille, interview) nevertheless believe that racial integration and progress is taking place at many levels in the education system; however, this is primarily occurring in middle-class areas where students have relatively equal economic bases, such as at private schools and universities.

As with education, almost all interviewees raised the role that mass media can play in building non-racialism. ${ }^{10}$ For many it has the potential to perform a critical task in propagating values of non-racialism, although overall there is a sense that the sector does not do enough to promote these principles. For Zille, Mantashe and Chaskalson, outlets that produce public media, such as newspapers and television stations, need to work on their 'analytical ability'. Zille raises concerns that the media demonstrate a lack of understanding of important issues and a lack of analytical capacity; Chaskalson agrees, suggesting that the level of discourse in newspapers is very poor. Mantashe feels there is too small a group of commentators influencing thinking in society: 'the current analysts are overexposed'.

Several respondents indicated concern that mass media outlets present and consolidate prejudicial views. For Gandhi it is "prejudiced in the sense that the media... condemns people, it character assassinates people... and once you start doing that ... you generalize. You think that because this person did this, that all the people who belong to that group are the same'. Both Hogan and Ngwane further discussed how advertisements, in particular, involve racial profiling, manipulating and working with stereotypes rather than challenging them. In a similar vein, the media is accused of succumbing to inherent and inherited racism. Ngwane talks about how White voices are used to imply credibility: 'even when comrades... do their documentaries, the voiceover is always done by a White person'. Lastly, for Chikane and Naidoo, media houses need to acknowledge 
that they are a site of racial struggle. Although there is now Black ownership of media houses, they still need to deal with the perception that the media is controlled by the affluent White community.

In light of these concerns, respondents looked to the roles that the media could and should play in supporting non-racialism. First, some respondents did note the positive role played by the mass media outlets in responding to genuine multiracial impulses in the country around key moments, such as the 2010 Soccer World Cup, which affirm our common identity as South Africans (Hogan, interview). Williams-de Bruyn highlights the role of electronic media, some television talk shows, and the Primedia 'Lead SA' campaign in bringing out and debating important issues.

Many felt that the media could play an educational role in promoting the values of non-racialism. For Mbeki, 'the media is good from the point of view of education'; meanwhile, Mantashe explained that 'feature articles must be educational, help us think outside the box, promote ideas. That is where the idea of nonracialism belongs'. Other respondents stressed the potential for media to provide deeper analysis and to strengthen and promote debate on the idea of non-racialism. For Haffajee, the media should have intelligent race debates, not hide away from tough questions, and continuously support people in developing a theory of what non-racialism might look like in a democracy. As she notes, 'we have race debates, but we don't have debates about non-racialism'.

Important as the media is in supporting non-racialism, there are considerations to bear in mind when discussing its role. Haffajee, as an editor, explains that the media does have a responsibility to report on what is actually happening in society, not just what it is in the interest of nation-building to report; it has to balance national interest with public interest. Makhanya, who is also an editor, states that the media has to reflect society as it is in addition to as it should be. One of the biggest contributions to non-racialism that he feels the media can make is to avoid reporting racially separate interests in the country, but instead create one conversation for all South Africans.

Finally, the importance of widespread, open and inclusive debate in building non-racialism was raised by many respondents. It is necessary to have forums where people can 'sit and talk honestly and openly; say things without fear of being attacked' (Gandhi, interview). Mbeki feels that as a country we are not discussing the legacy of racism sufficiently. His concern is that people often accuse others of 'playing the race card' in order to stop discussion. It is problematic to take the approach that apartheid is long gone and there is no more need for debate, because society remains fundamentally structured according to the racial legacy of the past 'and the failure to talk about it means, in the end, that we don't act as purposefully and consistently as we should'. De Klerk agrees that there should be ongoing, solution-orientated dialogue across colour and ethnic lines about the process of building a non-racial society, and that 'moderate' voices must 'make themselves heard'. As part of the role of debate, respondents also discussed the importance of giving space to analysts who 'interrogate the structure of race and non-racialism today' (Haffajee, interview). Yacoob 
concludes: 'Despite everything, the most powerful tool in achieving non-racialism is to talk to people'.

\section{Conclusion}

What does non-racialism mean to leaders in South Africa today? Do they envisage building a non-racial society, and if so, what challenges do they believe face us in doing so? First, and significantly, this research has demonstrated that non-racialism is a term still ambiguously understood and defined by South African leaders. Some respondents subscribed to a strict literal meaning of the term-overcoming racial differentiation-but for many, non-racialism must involve an initial acknowledgement of racial difference before this difference can be surmounted. Debates about the meaning of non-racialism raise two questions: how can we move forward in building a non-racial South Africa where there is divergence among leaders about what this concept should embrace, and what are the challenges to understanding non-racialism in the context of a politically free, yet highly unequal, society? In terms of the latter question, the complexity of tackling socio-economic inequality derived chiefly from apartheid racial policies, while at the same time fostering a society that is not focused on racial identity, is a challenge leaders will have to address if they want to pursue the ideal of non-racialism.

Respondents had a much stronger sense of the challenges impeding the achievement of non-racialism, such as socio-economic inequality between race groups and poor leadership, particularly from the ANC. However, several interviewees (Chikane, interview; Kathrada, interview; Makhanya, interview) reminded us not to become too overwhelmed by current challenges facing society; South Africans must not forget the long road the country has travelled on the non-racial path. For Chikane:

When I grew up... if you wanted to buy something, if you were White you would go into the shop to buy the thing, if you were black you had to buy them through the window. So, for people who grew up like that, 1994 was a huge breakthrough; it was a revolution... The younger generation who has not lived through that think that nothing has changed.

Other respondents agree there has been significant racial change. For Mbeki, the biggest success has been in the political sphere-'I think the political system in the country has been de-racialised'-although he notes that this is 'probably the easiest sphere' to change. Mbete agrees that non-racial progress is visible when you 'see a lot of black people joining the traditionally White parties in the country... there is a side of me that wants to congratulate them for getting over that mental barrier'. For de Klerk, the relative ease with which the transition in education and the breakdown of residential segregation have taken place point to the fact that we are on the right track: 'So I am positive. If I put the negatives and the positives on a scale I remain positive about the future of South Africa and our capacity to fulfil our full potential'.

That said, the majority of respondents still raised major concerns about the progress, or lack of such, toward the goal of non-racialism. Esack feels that ' $\mathrm{t}] \mathrm{he}$ state of non-racialism in our country at the moment is badly framed and under 
threat', and Makhanya agrees that 'right now we find ourselves in a very bad space in terms of race relations. Stuff is bubbling to the surface; we are being thrown back into our corners and the champion of non-racialism, the ANC, is not leading'. Coovadia's concern is that 'race has become more amplified, particularly in the last few years because populism has crept into our politics... there are some leaders that are actually trying to gain support through populist ideas, and one of those ideas is the issue of race'. He feels that 'we just lost the values we grew up with'. Gandhi agrees that 'we haven't come very close to achieving the kind of society we want to see'. Finally, for Haffajee,

Non-racialism is a kind of. . . fading dream... in our public life, in our public debate. Instead now, if you look at popular culture, I would think that the identity of young South Africans is that they live in a multiracial society where White people still control the wealth. So it's a movement from non-racialism to multiracialism.

Given these pessimistic views, do leaders see a way forward in building a nonracial South Africa? Understanding the potential that different sectors of society, such as education and media, can play in fostering non-racialism does provide a positive step in the direction of its achievement. For a large number of respondents, a crucial step towards achieving non-racialism is to have strong, visionary leadership driving forward non-racial principles. This view is significant, given that the respondents in the research project are leaders in their own spheres; it further points to the potential for non-racialism to become, once again, an important political and social project.

Although many of the leaders interviewed were highly critical of current leadership on non-racialism, in particular that of the ANC, several maintained that leading a non-racial vision is not only the responsibility of ANC leaders, but of leaders across the board, including business, religious, political and cultural leaders: 'We all have to be part of breaking down the myth of differences based on skin colour' (Hanekom, interview). As Mbeki points out, no one is going to sit down and draw up tasks for everybody. Instead, as Vadi correctly explains, we are all going to have to consciously challenge racism in this society, and how effective we are will depend not just on one group, but on all organisations, individuals and movements in society who subscribe to the values of non-racialism. Certainly the views provided by leaders in this research are through-provoking and noteworthy; ultimately, however, building a non-racial South Africa is the responsibility of all who share this vision and live in this country.

\section{Notes}

*Dr Fiona Anciano-White, Senior research associate, Centre for the Study of Democracy, University of Johannesburg, South Africa. Email: fiona.a.white@gmail.com.

** Jonny Alubu Selemani, junior researcher, Centre for the Study of Democracy, University of Johannesburg, South Africa. Email: jaselemani@uj.ac.za.

1. Unless otherwise stated, all quotations in this text are taken from interviews conducted by the authors between July and September in 2011, as per the reference list on behalf of the Ahmed Kathrada Foundation. The transcripts will be made publicly available on the Foundation's website imminently (www. kathradafoundation.org). 


\section{F. ANCIANO-WHITE AND J.A. SELEMANI}

2. Former state president de Klerk focused on the idea of multiculturalism as a value to strive for in society. Multiculturalism, according to McDonald (2006, p. 182), favours recognising all identities, while acknowledging that real recognition can involve treating different identities differently. For some multiculturalists (Song, 2010), mere toleration of group differences falls short of treating members of minority groups as equal citizens; recognition and positive accommodation of group differences is required through 'group-differentiated rights'. Race has a more limited role in multicultural discourse. De Klerk makes the point that one must not confuse non-racialism with the absence of multiculturalism. For him, 'multiculturalism is as important in South Africa as nation building is'. We should not face a choice between non-racialism and multiculturalism, but rather, de Klerk argues, the Constitution binds us to strike a balance between these two concepts.

3. Frederikse's (1990, p. 13) reference to non-racialism as the 'unbreakable thread' between the ruling party and other alliance members suggests that non-racialism was a focal point for the ANC. However, the ANC only opened up membership to all races at the Morogoro conference in 1969, and even then 'non-Africans' were not permitted to sit on the ANC national executive (Callinicos, 1999, pp. 131-132).

4. Interviews for this project were conducted before charges were laid by the ANC against Youth League leaders for bringing the ANC into disrepute.

5. The ANC disciplinary committee suspended Julius Malema from the ANC for five years on 10 November 2011. At the time this article was submitted, it was unclear whether he would appeal this suspension.

6. For more detail on the ANCYL's views on non-racialism see Malema (2009).

7. For a recent philosophical debate on the role of Whites in South Africa see Vice (2011) and McKaiser (2011).

8. This comment was not an attack on Whites, but rather was made in the context of addressing the effects of apartheid and appealing to government to address poverty in South Africa.

9. Several other sectors were raised by respondents and are discussed in detail in the Kathrada Foundation report by Anciano-White and Selemani (2011). These sectors include business, religion, civil society, political parties and sports.

10. The media is a large sector, encompassing many forms, including new or electronic mediums, print, TV, etc. Although respondents did not always specify what type of media they were referring to in the comments, the majority alluded to traditional forms such as print media.

\section{References}

Ahmed Kathrada Foundation (2011), Research Project: Interviews with South African Leaders (Unpublished concept note, 5 June).

Ahmed Kathrada Foundation/Gauteng City Region Observatory (2011), 'Non-Racialism Focus Group Research Project 2011: Focus Group Transcription Pack', http://www.gcro.ac.za/project/non-racialism-ahmedkathrada-foundation

Anciano-White, F. and Selemani, J.A. (2011), 'Rethinking Non-Racialism: Reflections of a Selection of South African Leaders', Report presented at the Ahmed Kathrada Foundation Conference on Non-Racialism in Post-Apartheid South Africa: Contemporary Meanings and Relevance, 13 October, University of the Witwatersrand, Johannesburg.

The American Heritage Dictionary of the English Language (2009) Fourth Edition. (USA: Houghton Mifflin Company).

Berg, B. (2004), Qualitative Research Methods for the Social Sciences (Boston: Pearson Education).

Callinicos, L. (1999), 'Oliver Tambo and the Politics of Class, Race and Ethnicity in the African National Congress of South Africa', African Sociological Review, 3(1), pp. 130-51.

Everatt, D. (2009), The Origins of Non-Racialism: White Opposition to Apartheid in the 1950s (Johannesburg: Wits University Press).

Everatt, D. (2011), 'Non-Racialism in South Africa: Status and Prospects', presentation to Ahmed Kathrada Foundation Conference on Non-Racialism in Post-Apartheid South Africa: Contemporary Meanings and Relevance, 13 October, University of the Witwatersrand Johannesburg.

Frederikse, J. (1990), The Unbreakable Thread: Non-Racialism in South Africa (Johannesburg: Ravan Press).

Finchilescu, G. and Tredoux, C. (2008), 'Intergroup Contact, Social Context and Racial Ecology in South Africa', in: U. Wagner, L. Tropp, G. Finchilescu and C. Tredoux (eds), Improving Intergroup Relations: Building on the Legacy of Thomas F. Pettigrew (United States: Wiley-Blackwell).

Finchilescu, G., Tredoux, C., Muianga, L., Mynhardt, J. and Pillay, J. (2006), 'Testing Contact Theory in South Africa: A Study of Four Universities', paper presented at the conference Contact and Intergroup Relations: 50 Years On, 6-9 July, Ithala Game Lodge, South Africa.

Gibson, J. (2004), 'Does Truth Lead to Reconciliation? Testing the Causal Assumptions of the South African Truth and Reconciliation Process', American Journal of Political Science, 48, pp. 201-217. 
Malema, J. (2009), 'THE NDR, African Leadership and Non-Racialism', ANC Youth League, 15 August, http:// www.ancyl.org.za/show.php?id=5873

Maré, G. (2003), 'Non-Racialism' in the Struggle against Apartheid', Society in Transition, 34(1), pp. 13-37.

Maré, G. (2009), 'Making a distinction', The Witness, 23 September.

Maré, G. and Kinners, A. (2011), 'It is Impossible to Research Non-Racialism at a Societal Level - What Then? Reflections on Race Thinking by South Africans', presentation to Ahmed Kathrada Foundation Conference on Non-racialism in Post-Apartheid South Africa: Contemporary Meanings and Relevance, 13 October, University of the Witwatersrand, Johannesburg.

May, T. (2001), Social Research: Issues, Methods and Process (Buckingham: Open University Press).

McDonald, M. (2006), Why Race Matters in South Africa (Scottsville: UKZN Press).

McKaiser, E. (2011), 'Confronting Whiteness', Mail and Guardian, July 1.

Motlanthe, K. (2010), 'The ANC and Non-Racialism Today', in: Ahmed Kathrada Foundation', Non-racialism An Unbreakable or Very Fragile Thread of South Africa's Democracy? (Johannesburg: Ahmed Kathrada Foundation).

Song, S. (2010), 'Multiculturalism', in: E.N. Zalta (ed.), The Stanford Encyclopedia of Philosophy, http://plato. stanford.edu/archives/win2010/entries/multiculturalism

Taylor, R. (1994), 'South Africa: from “Race” to Non-Racialism?' in: P. Ratcliffe (ed.), “Race”, Ethnicity and Nation: International Perspectives on Social Conflict (London: UCL Press).

Tutu, D. (2011), Emeritus-aartsbiskop dr. Desmond Tutu se toespraak http://www.youtube.com/watch?v= mfH8rQoAnRg\&feature =youtu.be

Vice, S. (2011), 'Why my Opinions on Whiteness Touched a Nerve', Mail and Guardian, 2 September.

\section{Interviews}

Cachalia, Firoz (8 August 2011). Former MEC, University of Witwatersrand Law academic, Johannesburg.

Chaskalson, Arthur (25 August 2011). Former Justice of the Constitutional Court, Johannesburg.

Chiba, Laloo (14 July 2011). Former Member of Parliament and member of the Transvaal Indian Congress, Johannesburg.

Chikane, Frank (18 August 2011). Faith based leader and Former Director General: Office of the President, Soweto.

Coovadia, Cassim (10 August 2011). Managing Director, Banking Association of South Africa, Johannesburg.

Cronin, Jeremy (18 August 2011). Deputy Minister of Transport, Pretoria.

De Klerk, F.W. (8 August 2011). Former South African President, Cape Town.

Dlamini, Sidumo (19 July 2011). COSATU President, Johannesburg.

Esack, Farid (19 August 2011). Muslim scholar, writer, anti-apartheid activist, Johannesburg.

Gandhi, Ela (16 August 2011). Former Member of Parliament, Durban.

Haffajee, Ferial (3 August 2011). Editor of the City Press, Johannesburg.

Hanekom, Derek (1 August 2011). Deputy Minister of Science and Technology, Pretoria.

Hogan, Barbara (21 July 2011). Former Minister of Public Enterprises, Johannesburg.

Kathrada, Ahmed (7 July 2011). Anti-apartheid activist, Johannesburg.

Makhanya, Mondli (11 August 2011). Editor-in-Chief of Avusa newspapers, Johannesburg.

Mantashe, Gwede (4 August 2011). ANC General Secretary, Johannesburg.

Mbeki, Thabo (28 September 2011). Former South African President, Johannesburg.

Mbete, Baleka (25 August 2011). ANC Chairperson, Johannesburg.

Moosamy, Magdalene (3 August 2011). ANC Youth League spokesperson, Pretoria.

Naidoo, Prema (22 July 2011). ANC Chief Whip, City of Johannesburg, Johannesburg.

Ngwane, Trevor (13 July 2011). Social movement activist, Johannesburg.

Satgar, Vishwas (31 August 2011). Co-organiser, Democratic Left Front, Johannesburg.

Vadi, Ismail (15 July 2011). ANC MEC for Transport, Gauteng, Johannesburg.

Williams-De Bruyn, Sophie (13 July 2011). ANC Member of Parliament, Johannesburg.

Yacoob, Zakeria (11 July 2011). Constitutional Court Judge, Johannesburg.

Zille, Helen (1 August 2011). Leader of the Democratic Alliance, Cape Town. 